\title{
Panduan Kesehatan Bagi Ibu Hamil Dan Anak Berbasis Android Mobile
}

\author{
Lufila $^{1}$, Muhammad Zulfadhilah ${ }^{{ }^{*}}$ \\ ${ }^{1}$ Program Studi Teknologi Infromasi Universitas Sari Mulia Banjarmasin \\ *correspondence author: 085251239595, E-mail: zulfadhilah@unism.ac.id
}

DOI: $\underline{10.33859 / \mathrm{dksm} . v 11 \mathrm{i} 1.582}$

Abstrak
Latar Belakang: Kesehatan sebagai suatu kebutuhan dasar bagi setiap orang merupakan faktor
penentu kualitas Sumber Daya Manusia. Tetapi terkadang kesehatan itu sering terlupakan karena
berbagai macam faktor, dan yang paling sering adalah karena kesibukan seseorang itu sendiri. Selama
ini para ibu mendapatkan informasi tentang kehamilan dan anak dari posyandu atau di puskesmas
serta dari bidan atau dokter di lingkungan sekitar mereka. Kekurangan dari fasilitas layanan
kesehatan tersebut adalah waktu pelaksanaannya yang tidak bisa dilakukan setiap saat. Sedangkan
kendala untuk mendapatkan informasi dari bidan, dokter maupun puskesmas di lingkungan sekitar
mereka adalah kesibukan dari orang tersebut serta jarak yang terkadang menyusahkan untuk
mendapatkan informasi tersebut.
Tujuan: Untuk pemenuhan sistem informasi kesehatan ibu hamil dan anak yang lebih cepat saat ini
telah banyak terdapat aplikasi-aplikasi berjenis mobile yang mampu memenuhi kebutuhan informasi
kesehatan ibu hamil dan anak
Metode: Metode Observasi dan literatur review.
Hasil: Hasil dari penelitian ini adalah terciptanya sebuah aplikasi, aplikasi ibu dan anak ini berbasis
Android yang berguna untuk mendapatkan informasi-informasi bagi ibu hamil dan anak berdasarkan
parameter-parameter yang dibutuhkan untuk setiap menu-nya
Kesimpulan: Kesimpulan pada penelitian ini adalah sistem informasi yang berbasis Android ini
dibuat untuk membantu pemantauan kesehatan bagi ibu hamil dan anak yang ada dalam
kandungannya.
Kata Kunci: Android, Kesehatan, Kehamilan, Pakar


Abstract

Background: Health as a basic need for everyone is a determining factor in the quality of Human Resources. But sometimes health is often forgotten due to various factors, and most often it is because of one's own busy schedule. During this time mothers get information about pregnancy and children from Integrated Healthcare Center or at the Public health center and from midwives or doctors in their immediate surroundings. The weakness of the health service facility is the time of its implementation which cannot be done at any time. While the obstacle to get information from midwives, doctors and health centers in their immediate surroundings is the busyness of the person and the distance that is sometimes difficult to get the information.

Purpose: To fulfill the health information system for pregnant women and children faster, there are now many mobile applications that are able to meet the health information needs of pregnant women and children

Method: Observation method and literature review.

Results: The results of this study are the creation of an application, this Android-based mother and child application that is useful for obtaining information for pregnant women and children based on the parameters needed for each menu

Conclusion: The conclusion of this research is an Android-based information system created to help monitor health for pregnant women and children in the womb.

Keywords: Android, Health, Pregnancy, Experts

\section{Pendahuluan}

Perkembangan komputer saat ini berperan besar dalam memberikan dukungan kepada manusia untuk menyelesaikan berbagai macam persoalan baik dalam bidang industri, perdagangan, pendidikan, dan hampir seluruh bidang kehidupan manusia (Ratnasari et al., 2018). Komputer kini telah digunakan secara luas, terutama dalam bidang Kesehatan. Komputer / mesin saat ini yang dilengkapi dengan berbagai kemampuan mampu mengenali kondisi manusia, salah satunya terkait dengan kesehatan (Zulfadhilah, 2019).
Sistem informasi kesehatan (SIK) adalah salah satu dari 6 building block atau merupakan komponen utama dalam suatu sistem Kesehatan (Setiyadi \& Hakam, 2015).

Penerapan teknologi computer dalam bidang Kesehatan sudah sangat banyak, contohnya tentang penggunaan Sistem Pakar Diagnosa Gangguan Kehamilan Dengan Metode Forward Chaining yang dilakukan oleh (Dwi Ratnasari \& Sutariyani, 2015) pada penelitiannya. Selain itu penggunaan teknologi dalam deteksi dini gangguna psikologis pada anak yang dilakukan oleh (Zulfadhilah, 2019) 
pada penelitiannya yang lau, kemudian penelitian yang dilakukan oleh (Krisnanik, 2017) tentang Perancangan Model Basis Data Berbasis Pakar Gangguan Rahim Dan Kesehatan Janin serta penelitian yang dilakukan oleh (Mambang \& Byna, 2017) tentang Analisis Perbandingan Algoritma C.45, Random Forest Dengan Chaid Decision Tree Untuk Klasifikasi Tingkat Kecemasan Ibu Hamil. Hal tersebut membuktikan bahwa semakin bermanfaatnya kemajuan teknologi saat ini yang mampu membantu masyarakat.

Pada tulisan ini akan dipaparkan tentang sebuah system informasi untuk ibu hamil dan anak dengan menggunakan media smartphone Android, diharapkan dengan adanya hal ini bisa membantu para ibu hamil dan anaknya untuk selalu mengetahui tentang hal-hal terkait tentang kesehatan pada masa hamil dan pada anak.

\section{Metode}

Proses penelitian ini dilaksanakan dengan melakukan observasi dengan melibatkan mahasiswa jurusan kebidanan serta studi literatur untuk mengetahui apa saja yang diperlukan dalam system informasi yang akan dibuat. Pada pembuatan rancang bangun system informasi ini dilakukan dengan menggunakan SDLC (System Development Life-Cicle) yang merupakan salah satu metode dalam pengembangan atau pembuatan sebuah aplikasi atau software. Metode ini juga menjadi kerangka penelitian seperti gambar dibawah:

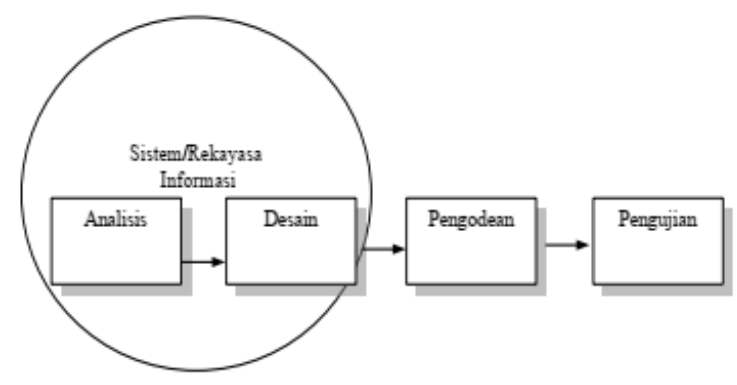

Gambar 1 Kerangka Penelitian (Firmansyah \& Udi, 2017)

1) Analisis: Pada tahapan ini analisis sudah masuk dalam pembuatan diagram aktifitas dan use case yang merupakan diagram dialog antar pengguna dengan sistem.

2) Design: Pada tahapan ini dilakukan pembuatan gambaran awal dari sistem, cara kerja sistem, dan antarmuka sistem yang akan dibuat. Kegiatan yang dilakukan dalam perancangan meliputi perancangan database dan perancangan antarmuka.

3) Pengkodean: Pada tahapan ini sudah masuk pada implementasi pembuatan program sistem informasi yang dimaksud.

4) Pengujian: Tahapan ini dilakukan untuk mengetahui apakah prosedur yang digunakan dalam mengolah data menjadi informasi yang diharapkan atau tidak. Dengan pengujian tersebut pengguna dapat memberikam pendapatnya mengenai sistem.

\section{Hasil}

Pada penelitian yang telah dilakukan didapatkan hasil berupa sebuah sistem informasi tentang ibu hamil dan anak yang 
disajikan dalam bentuk mobile, sehingga bisa digunakan pada smartphone Android. Aplikasi ini merupakan aplikasi mobile berbasis Android yang berguna untuk mendapatkan informasi-informasi bagi ibu hamil dan anak berdasarkan parameter-parameter yang dibutuhkan untuk setiap menu-nya.

Fitur utama sistem ini adalah informasi tentang keadaan ibu hamil dan anak/janin. Penggunaan fitur tersebut mengharuskan memasukkan tanggal terakhir haid, berat badan ibu hamil, dan tinggi ibu hamil. Dari inputan tersebut akan diketahui berat badan ideal ibu hamil, perkiraan tanggal kelahiran, dan umur janin. Setelah diketahui umur janin, pengguna dapat melihat informasi mengenai perkembangan janin dengan usia janin yang telah diketahui tadi. Berdasarkan umur janin tadi, aplikasi juga akan memberikan informasi senam bagi ibu hamil sesuai dengan umur dari janin yang dikandung ibu. Semua data-data informasi tadi direkap kedalam database tiap minggunya untuk mengetahui perkembangan kesehatan ibu hamil berdasar berat badan ideal ibu hamil tersebut. Pada sistem ini pengguna juga akan diberi informasi mengenai kebutuhan gizi ibu mingguan berdasarkan perkembangan ibu hamil.

Pada aplikasi ini juga terdapat beberapa fitur tambahan guna membantu ibu hamil dan anak dalam mendapatkan informasi kesehatan mereka. Adapun fitur-fitur tambahan tersebut adalah untuk mengetahui masa subur wanita, penanganan keluhan kehamilan, pencatat waktu kontraksi pada ibu hamil, penentu kesehatan anak, menghitung kebutuhan air harian, panduan merawat payudara bagi ibu hamil dan menyusui, serta penentuan lokasi rumah sakit bersalin terdekat.

Pada gambar di bawah ini merupakan antarmuka sistem atau aplikasi yang telah dibuat oleh penulis:

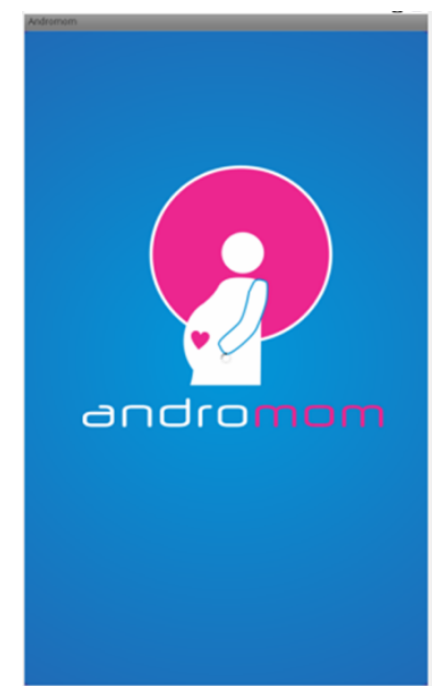

Gambar 2 Form Loading

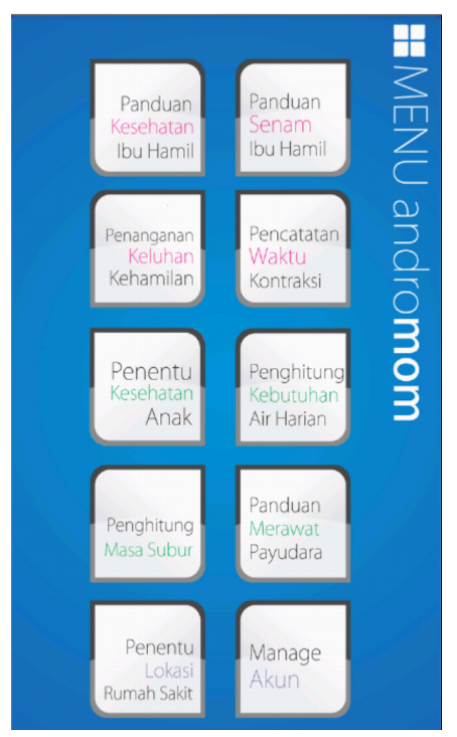

Gambar 3 Form Utama 
Dinamika Kesehatan Jurnal Kebidanan dan Keperawatan Vol 11 No. 1 Juli 2020 ( ISSN: 2086-3454 EISSN: 2549-4058) url: http://ojs.dinamikakesehatan.unism.ac.id DOI : https://doi.org/10.33859/dksm.v11i1 Panduan Kesehatan Bagi Ibu Hamil Dan Anak Berbasis Android Mobile

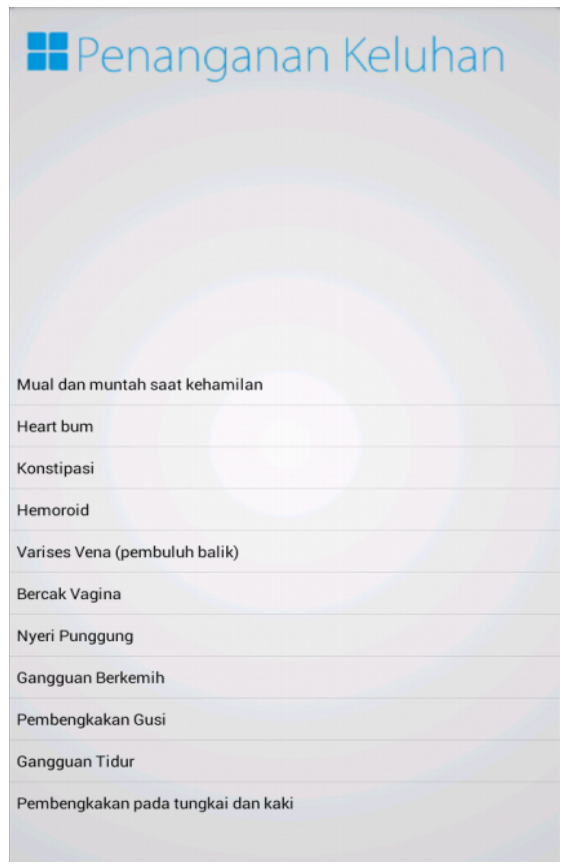

Gambar 4 Form Penangan Keluhan

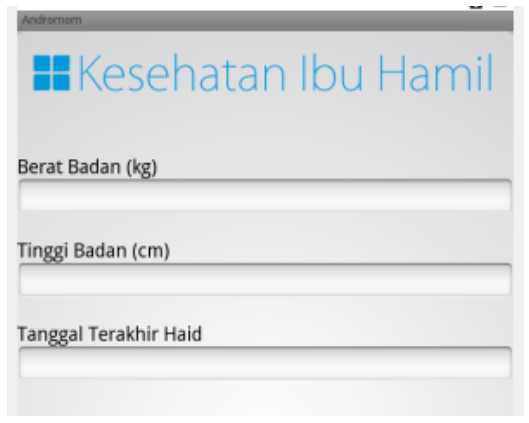

Gambar 5 Form Data Ibu Hamil

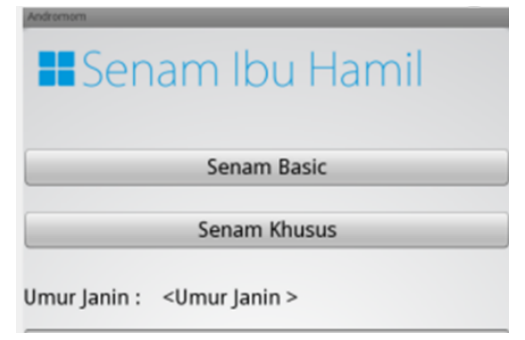

Gambar 6 Form Informasi Senam untuk Ibu Hamil

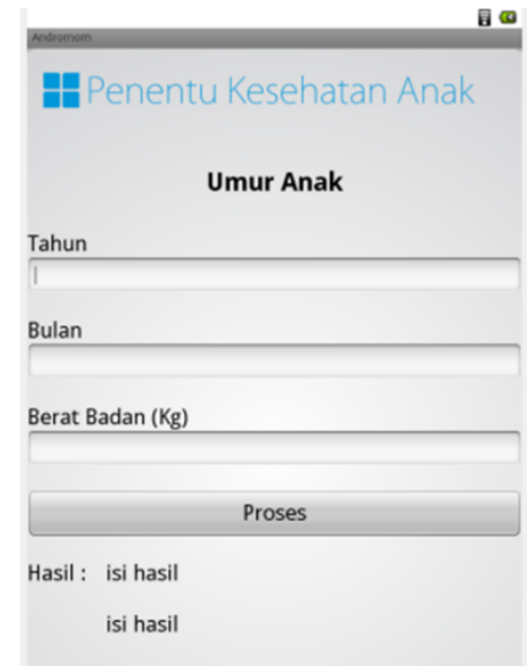

Gambar 7 Form Kesehatan Anak

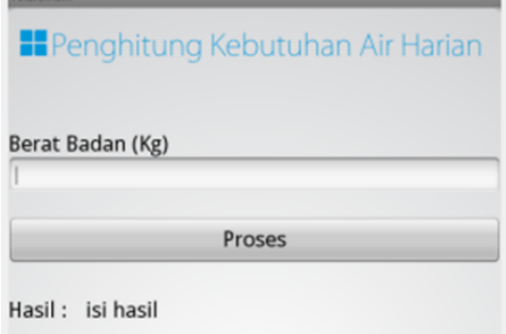

Gambar 8 Form Penghitungan Kebutuhan Air

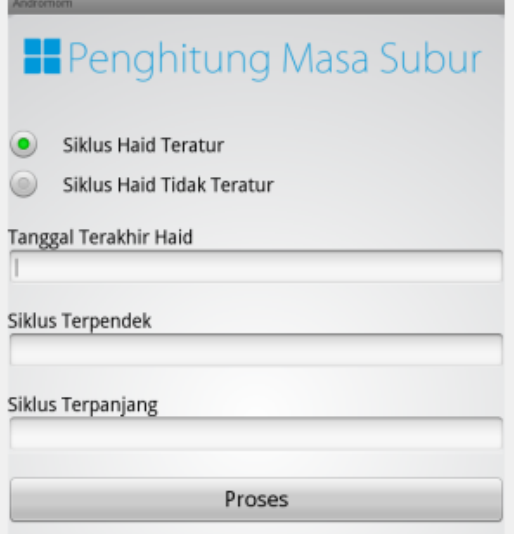

Gambar 9 Form Penghitungan Masa Subur 


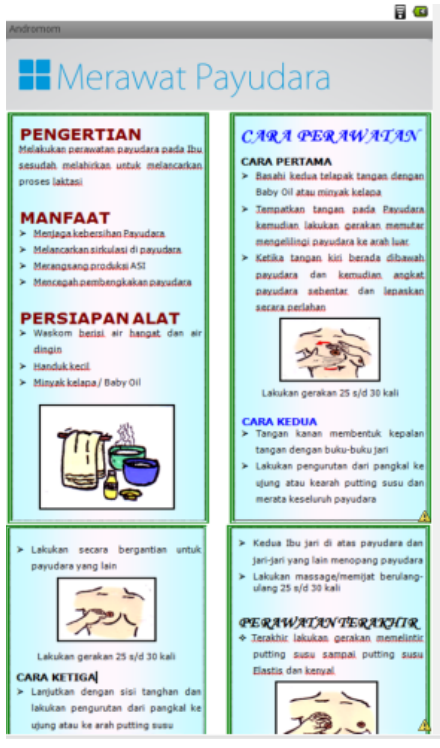

Gambar 10 Form Informasi Cara Merawat

Payudara

Pada gambar di atas merupakan beberapa form antar muka pada aplikasi yang dibuat oleh peneliti.

\section{Pembahasan}

Pada aplikasi ini terdapat beberapa fitur yang sangat diperlukan oleh ibu hamil. Dari fitur-fitur tersebut disampaikan informasi penting tentang hal-hal yang berhubungan dengan informasi kehamilan dan kesehatan ibu hamil. Informasi tentang kesehatan ibu hamil dan anak, kemudian informasi perkembangan janin dan lainnya.

$$
\text { Aplikasi ini juga memberikan }
$$

informasi tentang senam hamil yang merupakan olahraga yang bisa membantu ibu hamil tetap bugar, hal ini juga disampaikan oleh (Pujiastuti, 2014) tentang pentingnya senam pada ibu hamil. Selain itu (Pujiastuti, 2014) menyebutkan bahwa perlunya informasi terkait tentang kehamilan pada wanita, karena informasi ini sangatlah penting diketahui oleh para wanita yang sedang hamil anak pertama.

Pengetahuan terkait kehamilan sangat diperlukan oleh wanita yang baru mengalami fase ini, berdasarkan dari penelitian yang dilakukan oleh (Elliana \& Kurniawati, 2015) menyebutkan bahwa dengan adanya penggunaan teknologi mobile seluler (mHealth) sebagai strategi promosi kesehatan diharapkan mampu memfasilitasi informasi lebih dekat, menjangkau individu sehat tetapi tidak teratur kontak ke pelayanan kesehatan. Berdasarkan hal tersebut maka aplikasi/sistem yang telah dibuat ini bisa menjadi media promosi kesehatan khususnya pada ibu hamil.

\section{Daftar Pustaka}

Dwi Ratnasari, D., \& Sutariyani. (2015). Sistem Pakar Diagnosa Gangguan Kehamilan Dengan Metode Forward Chaining. Jurnal ilmiah go infotech, 21(2), 25-31.

Elliana, D., \& Kurniawati, T. (2015). Perbedaan Pengetahuan Dan Persepsi Ibu Hamil Terhadap Penerapan Model Sms Gateway. Jurnal Kesehatan Masyarakat, 10(2), 203. https://doi.org/10.15294/kemas.v10i2.33 82

Firmansyah, Y., \& Udi, U. (2017). Penerapan Metode SDLC Waterfall Dalam Pembuatan Sistem Informasi Akademik Berbasis Web Studi Kasus Pondok Pesantren Al-Habib Sholeh Kabupaten Kubu Raya, Kalimantan Barat. Jurnal Teknologi Dan Manajemen Informatika, 4(1). https://doi.org/10.26905/jtmi.v4i1.1605 
Krisnanik, E. (2017). Perancangan Model Basis Data Berbasis Pakar Gangguan Rahim Dan Kesehatan Janin. Seminar Nasional Teknologi Informasi Dan Multimedia 2017.

Mambang, \& Byna, A. (2017). Analisis Perbandingan Algoritma C.45, Random Forest Dengan Chaid Decision Tree Untuk Klasifikasi Tingkat Kecemasan Ibu Hamil. Semnasteknomedia Online, $5(1)$, 103-108. https://ojs.amikom.ac.id/index.php/semn asteknomedia/article/view/1771

Pujiastuti, A. (2014). Konsep Kehamilan Sehat: Upaya Mencetak Generasi Cerdas. Artikel Kesehatan Nasional, 1-9. http://eprints.uad.ac.id/8172/1/konsep kehamilan sehat $\% 2 \mathrm{C}$ upaya mencetak generasi cerdas.pdf

Ratnasari, D., Qur'ani, D. B., \& Apriani, A. (2018). Sistem Informasi Pencarian Tempat Kos Berbasis Android. Jurnal INFORM, 3(1), 32-45. https://doi.org/10.25139/ojsinf.v3i1.657

Setiyadi, N. A., \& Hakam, F. (2015). Analisis Pelaksanaan Sistem Informasi Kesehatan di Klinik Muhammadiyah Medical Center (MMC) Universitas Muhammadiyah Surakarta. Jurnal IKESMA, 11(Mmc), 15-24.

Zulfadhilah, M. (2019). Sistem Pakar Untuk Diagnosa Gangguan Psikologis Anak Dengan Algoritma Breadth First Search (BFS). JITEKH, 7(1), 15-22. 